\title{
Job Satisfaction and Employee's Unionization Decision: The Mediating Effect of Perceived Union Instrumentality
}

\author{
Hongmei Shan ${ }^{1,}$ Enhua $\mathrm{Hu}^{2}$, Lujie Zhi' ${ }^{2}$, Long Zhang ${ }^{3}$, Maolong Zhang ${ }^{2}$ \\ ${ }^{1}$ Faculty of Science, Nanging University of Posts and Telecommunications, Nanjing, ${ }^{2}$ College of Economics and \\ Management, Nanjing University of Aeronautics and Astronautics, Nanjing, ${ }^{3}$ School of Business, Hohai University, \\ Nanjing (China)
}

shanbm710710@163.com, ebhu710519@sina.com, zbili@163.com, zhangl@bhu.edu.cn, ellen1025@foxmail.com

\section{Abstract:}

Purpose: Given the current lack of literature in the background of China labor force, this study aims to investigate the relationships among job satisfaction, perceived union instrumentality, and unionization from a reference-frame-based perspective and explore the referred relationships in the context of Chinese labor market.

Design/methodology/approach: The study introduces perceived union instrumentality as a mediator to the relationship between job satisfaction and unionization. The applicability of western theories was tested in the Chinese context by a questionnaire survey on 390 employees who were working in private sectors of Jiangsu Province in China. Four hypothesis were proposed and tested by data analysis to verify the model.

Findings: The study found that most aspects of job satisfaction were negatively correlated with unionization and perceived union instrumentality, while perceived union instrumentality had a positive relationship with unionization. Perceived union instrumentality was also found to have a mediating effect on the relationship between job satisfaction and unionization.

Originality/value: The paper adapted and tested a number of western industrial relation theories in the backdrop of China, contributing to the gap in Chinese-context research by 
examining the relationships between job satisfaction, unionization and union instrumentality of Chinese employees. It pays a regular contribution to labor union studies both inside and outside China.

Keywords: job satisfaction, union instrumentality, unionization

\section{Introduction}

Labor union plays many roles like taking part in collective bargaining, leading political actions, fighting for community welfare and organizing recreational activities (Berkowitz, 1954). It acted as a powerful sword that safeguarded workers' rights (Kochan, 1979; Schnabel \& Wagner, 2007). In Western countries, labor unions thrived between the 1950s and 1960s. However, since the mid-1970s, the influence of the union started to falter and academics became interested in studying the antecedents to unionization (Blanchflower, 2006; Deery \& Cieri, 1991; Haberfeld, 1995) which means the act of employees joining a union.

Scholars were interested in a disparate range of unionization antecedents. Job satisfaction, subjective norms, labor union image and personal attitude were some of the common recurring themes in academic researches (c.f. Booth, 1985; Fiorito \& Greer, 1982; Guest \& Dewe, 1988; Iverson \& Kuruvilla, 2007; Khaleque, 1993; Parkes \& Razavi, 2004; Premack \& Hunter, 1988; Schriesheim, 1978; Voos, 1983). Among them, job satisfaction and union instrumentality, which means the perceived effective use of union movements to obtain outcomes that are beneficial to both organizations and employees, were two of the most important antecedents to unionization.

Employees involved in labor movements were usually dissatisfied with certain aspects of their jobs (DeCotiis \& LeLouarn, 1981; Heneman III \& Sandver, 1982; Visser, 2002; Dhammika, Fias \& Sam, 2012). However, researches indicate that job dissatisfaction was not sufficient to result in unionization (Premack \& Hunter, 1988) - employees would only unionize if they believed that the union could eliminate the source of their job dissatisfaction or improve their working conditions (Charlwood, 2002; DeCotiis \& LeLouarn, 1981; Kochan, 1979; Youngblood, DeNisi, Molleston \& Mobley, 1984).

In China, especially before the state's economic reformation started in 1980s, many organizations were owned by the state, and labor unions took orders from the Chinese central government. The main duty of the labor unions were to "assist" organizations to fulfill its social responsibility and to maintain social stability, but not to fight for the betterment of the working and living conditions of employees ( $\mathrm{Hu}, 2012$ ). Influenced by the Confucian philosophy, Chinese employees from the past rarely engage radical actions (such as going for strikes) to protect their rights. In most labor-management disputes, many employees rather yield to the 
employer or resign than to seek help from the union. Up to this point, the Chinese labor force did not really question the role that labor union should play, and they were not aware of the important role that unions could play in settling labor rights issues. After the economic reformation started, many private companies and foreign companies became key players in the Chinese market. Influence of the state greatly reduced and the cutthroat competitions of the market increased the number of labor-management disputes (White, 1996). In this backdrop, the Chinese started to relook and rethink about the role unions should play, while academic interests in union movements were also kindled (Ge, 2007; Anwar \& Sun, 2015).

Hitherto, Chinese labor union scholars were mainly interested in whether labor unions could protect employees' rights and whether they were independent from the Chinese central government (Zhang, 2009; Lu, Tao \& Wang, 2009; Friedman, 2014). In a recent review by Zhang (2009), he concluded that: (1) Chinese unions were not completely independent from the government, but their role was changing, and the government gave unions supports in the protection of workers' rights; (2) There were different types of unions, serving different purposes, and some of them had conflicting interests (e.g., government organized unions versus enterprise organized unions). (3) Due to the lack of labor organized rights-defendingorganizations in China, individual employees could only rely on the government and the labor unions to protect their rights.

In the wake of the recent series of labor disputes, the Chinese labors have realized the important role that labor unions could play, and Chinese labor unions started to expand their roles to taking part in labor rights protection. For example, in 2012, a television manufacturing joint venture enterprise in Pudong Jinqiao development zone announced its closure suddenly, displacing more than 1, 000 employees in the process. The union stepped in promptly to fight for the rights of the employees and eventually ensured that the employees were adequately compensated before the firm was liquidated ( $\mathrm{Li}, 2013 \mathrm{~b}$ ). In 8 May 2013, senior employees of a clothing company in Suzhou proposed to the union that a seniority-based wage system would be implemented to ensure the company's workforce stability and production reliability. The union negotiated with the company's board of directors and general manager on behalf of the senior employees and successfully come up with a win-win solution. The company was able to lower the senior employee turnover while higher salary for senior employees was achieved (Yao, 2013). In July 2013, the union of Cooper Chengshan (Shandong) Tire Company (subsidiary of a United States organization, Cooper Tire \& Rubber Company) organized employees to go for strike twice to resist India's Apollo Tyres from buying out the company with $\$ 2.5$ billion. The strikes were effective as Apollo Tyres quit the acquisition and Cooper Chengshan Tire Company gave up its restructuring plan ( $\mathrm{Li}, 2013 \mathrm{a}$ ). As a result of these successful cases, more employees were willing to join and/or form unions. For example, in 2014, Zhejiang Province had at least 1 million more new union members and more than 7, 000 newly established local unions. The percentage of unionized companies and unionized 
employees in the province both exceeded 85\% (Ding \& Wang, 2014). The influence of labor unions is most prominent among small and medium-sized private companies.

Labor unions are becoming more and more influential in the Chinese market. They play significant mediating role in the settling of labor-management disputes and in the protection of employee rights. This creates a positive cycle in which the actions taken by the unions lead to positive public opinions on union instrumentality, which could bring about higher rate of unionization, and higher unionization rate could produce even better union instrumentality perception.

Given that unions are now safeguarding and protecting the rights of employees, it is essential to ask, would employees have greater job satisfaction? Theoretically, one of the roles played by labor unions is to safeguard the welfare of the employees. Hence, we propose, union instrumentality should have a positive relationship with job satisfaction. If not, employees would be reluctant to join unions. Given the current lack of literature on this proposed relationship in the setting of China labor force, this study aims to investigate the relationship among job satisfaction, perceived union instrumentality, and individual decision to join union from a reference-frame-based perspective.

Hitherto, the relevant theories on the current focal topic were mostly developed by western scholars. These theories were created for the western labor market, and were tested with mainly western samples. Hence, it might have limited applicability in the Chinese market. It is the second aim of this paper to test for the generalizability of union instrumentality, job satisfaction and unionization literatures in the Chinese context.

\section{Literature Review}

\subsection{China Union}

Chinese labor unions are different from its Western counterparts (You, 2012; Budd, Chi, Wang $\&$ Xie, 2014). They are mass organizations led by the Chinese's central government. In China, labor unions play a dual role ( $\mathrm{Xu}, 2010)$, one is the protector of the employees' rights and the other is the broker between the employees and the management. According to the Labor union Law of the People's Republic of China (2001), Chinese unions have four basic functions: protecting employee rights, participating in firm management, educating employees, and directing organizational efforts toward central government's economic goals. Management participation is one special feature of the Chinese labor union. It refers to the process in which the union represents or organizes employees to take managerial roles in their respective organizations, or to conduct "democratic supervision in the enterprise". By democratic supervision, it refers to the process of the union supervising the organization to ensure that the employees are treated fairly. 
Influenced by socialism ideology, the Chinese government's interpretation of labor rights protection is not the same as its western counterparts (Zhao, 2008). The collective interest of the country as a whole is prioritized when the interests of individual employees are challenged. The principle of labor rights protection is to promote a win-win situation between workers and employers. Labor movements are expected to be conducted in a proactive, legitimate and scientific manner, and it should conform to the concept of "harmonious development" and "balanced planning". Nevertheless, according to Article 6 of Provisions on the Work of Enterprise Labor unions (for Trial Implementation, 2006), labor unions should assist companies in its operation such as protecting the rights and interests of employees, coordinating the relationship between labor and management, helping to build a harmonious workplace, and promoting the sustainable development of the company. From this perspective, labor unions should act as the key medium of communication between the management and employees, and as the coordinator of the two parties. Consequently, Chinese labor unions do have similarities with their western counterparts despite the existing differences.

\subsection{Hypotheses Development}

Job satisfaction can be influenced by individuals' perception on such factors as working condition and compensation and benefits (Smith, Hulin, \& Kendall, 1969), and it is a vital antecedent to unionization. Literature on the relationship between job satisfaction and labor union has come a long way. In early literature, scholars such as Klandermans (1986) and Charlwood (2002) proposed that dissatisfied employees were more likely to join a union. Although this frustration-aggression theory is intuitive, it lacks in the aspect of specifying what type of dissatisfaction would push an employee to join a union.

Wheeler and McClendon (1991) addressed this theoretical gap by proposing the dissonance theory. Based on Klandermans's (1986) theory, Wheeler and McClendon (1991) proposed that employees' intention to join a union could be attributed to the gap between their expectation and reality. For instance, employees could have expected their ideal job to be interesting and rewarding, they would become dissatisfied if their job is in fact boring and low-paying.

Empirical studies over the years have supported these two theories. In the 1980s, Guest and Dewe (1988) studied the changes in union density under the backdrop of Britain's political and economic reformation. They found that when employees were dissatisfied with their work, their awareness in union's role in protecting workers' rights would be heightened. Such priming effect upsurged the probability of an employee joining a union. In Waddington and Whitston's (1997) survey of 12 unions over the period of 1991 to 1993, they classified the respondents based on their position and industry, and found that manual workers were more likely to unionize. Meanwhile, there was a significant negative 
relationship between job satisfaction and unionization. Although the negative relationship between job satisfaction and unionization was found in both studies, they did not investigate the antecedent to the negative relationship.

About a decade later, Friedman, Abraham \& Thomas (2006) investigated the antecedent to unionization in the context of the United States. In their study, job satisfaction was inspected from four perspectives: career prospect, working environment, working stress and compensation and benefits. In the end, career prospect and compensation and benefits were found to have significant influences on employees' decision to unionize. Moreover, external factors (such as economic factors) were found to have more significant influences than internal factors.

The results of Friedman et al. (2006) were not replicable in the setting of another country. Zientara and Kuczyński (2009) used the conceptualization of job satisfaction from the previous study and conducted a research in Poland. In the Polish context, only career prospect was found to have a significant relationship with employees' decision to join a union. Notwithstanding the contradictory results found in Zientara and Kuczyński's (2009) study, we believed Friedman et al. (2006) framework should be applicable in the 2010s China. The primary reason behind this suspicion was that the Chinese 2010 s stage of economic development is comparable to the United States' stage of economic development a decade ago. It is likely for the Chinese labor force to be facing similar problems that had bothered the United States work force. Hence, it is more probable for Friedman et al. (2006) findings to be replicable in studies conducted in China. After consideration of the aforementioned factors, we propose:

\section{H1: Job satisfaction is negatively correlated with unionization.}

When deciding whether to join a union, employees would usually engage in a cost-benefit analysis first. On one hand, unions embrace the value of individual and employee rights (Klingner, Nalbandian, \& Llorens 2010), joining a union would bring them benefits (say the possibility of getting better working condition and a higher compensation), on the other hand, there still exists potential costs (say the probability of being dismissed). We consider that when the benefits outweigh the costs, employees would be more inclined to unionize. If not, they would hesitate. That is, individuals' perception of union instrumentality should have a positive relationship with unionization.

In Youngblood et al. (1984), the authors used job satisfaction, union instrumentality, union reputation and subjective norm to predict unionization. Positive relationships were found between union instrumentality, union reputation and subjective norm with unionization. Similar findings were also reported in Wheeler and McClendon (1991). The authors found that employees considered the potential benefits they could gain by joining a union before making their decision. Given that cost and benefit analysis is an essential part of most people's 
decision making process, we believe similar findings should be replicable in the Chinese context. Hence, we propose:

H2: Union instrumentality is positively correlated with unionization.

Kochan (1979) suggested that although job dissatisfaction could cause employees to think about joining a union, it is not sufficient to bring about action. Based on the results of Kochan's (1979) study, Premack and Hunter (1988) conducted a study in the United States to investigate the effect of compensation, job satisfaction and union instrumentality on unionization. The authors found that there was a significant negative relationship between job satisfaction and union instrumentality, and union instrumentality was a vital mediator between the two variables. Similar results were also found in other related researches.

Charlwood (2002) adopted Premack and Hunter's (1988) model to study the effect of job satisfaction, union instrumentality and political orientation on unionization. Although all three factors had significant influences on unionization, union instrumentality was the most critical one, and it had a significant positive correlation with unionization. Goeddeke and Kammeyer-Mueller (2010) surveyed 364 non-union employees in a United States public university to investigate the relationships of job satisfaction, union instrumentality, and unionization. The results suggested that union instrumentality was positively correlated to employee decision to join a union, and union instrumentality was found to be a mediator of the relationship between unionization and job satisfaction.

When employees received unfair treatments at work, they might compromise with the employer, resign and look for a new job, or join a union and fight for their rights (James \& Brett, 1984). Along with China's economic reformation, unions are changing their functions gradually, and they are also devoting more efforts toward the protection of employee rights. Under these circumstances, employees should have more confidence in union instrumentality than they did in the past. Such belief in unions' instrumentality should lead them to be more willing to join a union. Hence, we propose:

H3: Job satisfaction is negatively correlated with perceived union instrumentality.

H4: Perceived union instrumentality mediates the job satisfaction and unionization.

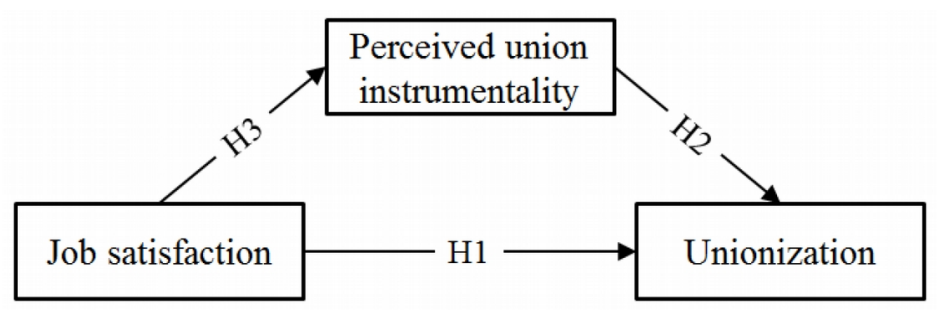

Figure 1. Conceptual model of job satisfaction and unionization 


\section{Methodology}

\subsection{Sample and Procedure}

We conducted a survey on employees working in private for-profit organizations from Jiangsu Province of China. A total of 450 questionnaires were distributed and 390 effective copies were received ( $86.7 \%$ effective response rate). A total of 30 companies had participated in this study. All respondents participated in the study of their own free will and the anonymity of the participants was ensured throughout the study. $68.5 \%$ of the respondents were males, $73.4 \%$ of them had at least a Bachelor degree, and $73 \%$ of them were non-managerial employees. The respondents had an average age of 32 year old, an average working experiences of 8 years, an average union membership of 4 years, and an average monthly compensation of 5 , 000 RMB.

The survey was made up of three parts. To make sure of the quality of the responses, we described the purpose of the survey in the first part and provided the participants with detailed instructions. The second part collected basic demographic information of the respondents. Some sample questions are "how long have you been working (including your stay in previous organizations and current organization)?" and "how long have you been a member of the union?" The third part contained questions that we used to measure job satisfaction, union instrumentality and unionization. All items in this section were arranged randomly.

\subsection{Measures}

Items used in the survey to measure job satisfaction, union instrumentality and unionization were all measured on a 5 -point Likert scale ( $1=$ strongly agree, $2=$ agree, $3=$ neutral, $4=$ disagree and $5=$ strongly disagree). We took note that the scales used in the current study were adopted from the western management literature. As westerners and Asians behave and think differently (Hofstede, 1998), it is likely that some of the items in these scales were not applicable to the Chinese context. Hence, we adapted the selected scales to the Chinese context, and conducted tests to make certain that our scales had sound psychometric qualities.

As the data was collected through a subjective survey, there was a concern for common method bias. To minimize the potential noise, we made an effort to ensure that no more than 15 questionnaires were collected from a single company. In addition, we conducted Harman's single factor test to check the acceptability of our data's common method variance by an unrotated exploratory factor analysis on the survey items. In total, we obtained a component loading of $24.587 \%$, which suggested the common method variance of the data was insignificant. 


\subsubsection{Job Satisfaction}

We adapted our scale of job satisfaction from Guest and Dewe (1988). Based on the framework of Friedman et al. (2006), job satisfaction could be studied from four dimensions, each of which was made up of four items - career prospect ("promotion opportunity", "company's recognition of employee performance", "company's concern for employee suggestions" and "job responsibilities"; $a=0.923$ ), working environment ("work flexibility", "skill development opportunity", "training opportunity" and "working condition"; $a=0.844$ ), working stress ("working hours", "difficulty of tasks", "task load" and "performance assessment system"; $\mathrm{a}=0.850)$ and compensation and benefits ("compensation", "bonus", "vacation" and "family time"; $a=0.888$ ). The overall a of job satisfaction was 0.880 .

\subsubsection{Union Instrumentality}

We adapted our scale of union instrumentality from DeCotiis and LeLouarn (1981) and Yao, Li and Han (2009). We operationalized union instrumentality into two dimensions: protection of labor rights ("the union can protect me from unfair treatment", "the union can help increase my pay", "the union can help negotiate for more benefits" and "the union can help improve the working environment"; $a=0.782$ ) and participation in management ("union leaders can attend the high-level meeting of the company", "the union can organize employee representative meeting to discuss the company development strategy", "the union can represent the employees in negotiating with company in case of labor-management conflict" and "the union can help coordinate the labor-management relations"; $a=0.743)$. The overall $a$ of union instrumentality was 0.758 .

\subsubsection{Unionization}

The items used to measure unionization were adapted from Kochan (1979). Unionization was operationalized into two dimensions: intention to join a union ("I will vote for the construction of a union" and "I believe that union is a useful organization and I will join it"; $a=0.666$ ), and intention to leave a union ("I am considering leaving the current union and joining another one" and "I have not benefited from the union"; $a=0.841)$. The overall a of unionization was 0.672 . 


\subsection{Construct Validity}

The measurements' construct validity was tested by conducting a Kaiser-Meyer-Olkin (KMO) measure of sampling adequacy test and a Barlett's test of sphericity (Field, 2009). The KMO measure for the referred three variables were: 0.589 (job satisfaction), 0.681 (union instrumentality) and 0.526 (unionization). The results of all Barlett's test of sphericity indicated that all the three variables were significant at the level of 0.01 . Given that the KMO values of all three variables were more than 0.50 and they were all significant at the 0.01 level, we proceeded further to the next step of constructing validity test by making an exploratory factor analysis on the data.

First, we conducted a principal components analysis with orthogonal rotation on all three scales. Other than "opportunity of skill development" and "performance assessment system" from job satisfaction, all other items had a factor loading greater than 0.50 , indicating that there was a good data aggregation and the common factors were effectively extracted in the factor analysis.

Job satisfaction's full model had a characteristic value greater than 1 , explaining $75.823 \%$ of the variation in the data. "Opportunity of skill development" and "performance assessment system" were removed from the final analysis as both items had loadings less than 0.50 . Union instrumentality's full model had a characteristic value greater than 1, accounting for $62.002 \%$ of the variation in the data. Unionization's full model had a characteristic value greater than 1 , accounting for $84.755 \%$ of the variation in the data. These outcomes suggested that our measurements had sound construct validity.

\section{Results}

Table 1 reported the means, standard deviations and correlations of all variables. We conducted a round of preliminary correlational analyses on the data. A significant negative relationship was found between job satisfaction and union instrumentality $(r=-0.379$, $p<0.01$ ), indicating that when employees were dissatisfied with their job, their assessment of the union's instrumentality would be more favorably. That is, when dissatisfied with their job, employees would have a tendency to consider union actions as an effective approach to help them. This finding makes sense to us as when someone is in need, he or she is likely to think of somebody else who is able to offer help. The relationship between job satisfaction and unionization was also found to be significantly negative $(r=-0.445, p<0.01)$, indicating that when employees were dissatisfied with their job, they would be more likely to join a union. This is in-line with the abovementioned findings. When someone needs help, and he or she thinks the union is able to help, the act of joining a union is more likely to happen. In addition, a significant positive 
correlation was found between union instrumentality and unionization $(r=0.327$, $p<0.01)$, indicating that when employees thought more favorably of a union's effectiveness in helping its members, they would be more likely to join it. This finding also makes sense to us as one is unlikely to join a union when its previous actions have indicated its incompetence in offering help to its members. These results gave preliminary supports to our model proposed before.

\begin{tabular}{|l|r|r|r|r|}
\cline { 2 - 5 } \multicolumn{1}{c|}{} & \multicolumn{1}{c|}{ Average } & $\begin{array}{l}\text { Standard } \\
\text { deviation }\end{array}$ & Job satisfaction & $\begin{array}{c}\text { Perceived union } \\
\text { instrumentality }\end{array}$ \\
\hline Job satisfaction & 2.86 & 0.73 & - & - \\
\hline Perceived union instrumentality & 3.05 & 0.56 & $-0.379 * *$ & - \\
\hline Unionization & 2.91 & 0.65 & $-0.445^{* *}$ & $0.327^{* *}$ \\
\hline
\end{tabular}

$* * p<0.01 . * p<0.05$.

Table 1. Descriptive statistics and correlation coefficient of variables

Next, we conducted a series of multiple regressions to test our hypotheses (see Table 2). The relationship between job satisfaction and unionization was examined. We introduced gender, age, education, working age and industry as control variables and unionization as the dependent variable in Model 1 . Then we tested the influence of the four dimensions of job satisfaction on unionization, and found main effects in all dimensions of job satisfaction except for working stress. Model 2 was tested for the influence of career prospect $(\beta=-0.712, p<0.01)$, Model 3 was tested for the influence of working environment on unionization $(\beta=-0.634, p<0.01)$, Model 4 was tested for the influence of working stress $(\beta=-0.292, p>0.05)$ and Model 5 was tested for the influence of compensation and benefits $(\beta=-0.875, p<0.01)$. Hence, Hypothesis 1 is partially supported by our data.

\begin{tabular}{|c|c|c|c|c|c|c|}
\hline & \multicolumn{6}{|c|}{ Unionization } \\
\hline & Model 1 & Model 2 & Model 3 & Model 4 & Model 5 & Model 6 \\
\hline Gender & $0.158 *$ & 0.069 & 0.054 & 0.035 & 0.027 & 0.044 \\
\hline Age & -0.091 & -0.053 & -0.036 & -0.065 & -0.048 & -0.024 \\
\hline Education & $-0.123 *$ & -0.098 & -0.027 & -0.038 & -0.014 & -0.017 \\
\hline Working age & 0.082 & 0.075 & 0.062 & 0.020 & $0.090 *$ & 0.058 \\
\hline Industry & 0.074 & 0.051 & 0.039 & 0.027 & 0.016 & 0.027 \\
\hline Career prospect & & $-0.712 * *$ & & & & \\
\hline Working environment & & & $-0.634 * *$ & & & \\
\hline Working stress & & & & -0.292 & & \\
\hline Compensation and benefits & & & & & $-0.875^{* *}$ & \\
\hline Job satisfaction & & & & & & $-0.793 * *$ \\
\hline
\end{tabular}

$* * p<0.01 . * p<0.05$.

Table 2. Regression analysis for the effect of job satisfaction on unionization 
To test $\mathrm{H} 2$, we regressed unionization on union instrumentality $(\beta=0.498, p<0.01)$. Then, to test H3, we introduced gender, age, education, working age and industry as control variables and union instrumentality as the dependent variable in Model 7 (see Table 3), and then examined the influences of the four dimensions of job satisfaction on union instrumentality. We found main effects in all dimensions of job satisfaction except for working stress. Model 8 was tested for the influence of career prospect $(\beta=-0.459, p<0.01)$, Model 9 was tested for the influence of working environment $(\beta=-0.524, p<0.01)$, Model 10 was tested for the influence of working stress $(\beta=-0.272, p>0.05)$ and Model 11 was tested for the influence of compensation and benefits $(\beta=-0.681, p<0.01)$. Hence, $\mathrm{H} 2$ was supported by the results of our analyses while $\mathrm{H} 3$ received only partial support.

\begin{tabular}{|c|c|c|c|c|c|c|c|}
\hline & \multicolumn{7}{|c|}{ Perceived union instrumentality } \\
\hline & Model 7 & Model 8 & Model 9 & Model 10 & Model 11 & Model 12 & Model 13 \\
\hline Gender & $0.102 *$ & 0.091 & 0.025 & 0.022 & 0.077 & 0.075 & 0.064 \\
\hline Age & -0.083 & -0.035 & -0.041 & -0.013 & -0.029 & 0.051 & -0.030 \\
\hline Education & $-0.073 *$ & $-0.081 *$ & -0.053 & -0.026 & -0.018 & 0.022 & -0.042 \\
\hline Working age & 0.039 & 0.031 & 0.021 & 0.015 & 0.026 & -0.019 & 0.023 \\
\hline Industry & 0.049 & 0.052 & 0.019 & 0.027 & 0.011 & 0.038 & 0.023 \\
\hline Career prospect & & $-0.459 * *$ & & & & & \\
\hline Working environment & & & $-0.524 *$ & & & & \\
\hline Working stress & & & & -0.272 & & & \\
\hline Compensation and benefits & & & & & $-0.681 * *$ & & \\
\hline Job Satisfaction & & & & & & $-0.486 * *$ & \\
\hline Unionization & & & & & & & $0.498 * *$ \\
\hline
\end{tabular}

$* * p<0.01 . * p<0.05$

Table 3. Regression analysis for the perceived union instrumentality

Next, we examined the potential mediating role that union instrumentality might play in the relationship between job satisfaction and unionization (H4). For a variable to be qualified as a mediator, three conditions must be satisfied (Masterson, Lewis, Goldman \& Taylor, 2000): the independent variable must be significantly related to the dependent variable in the absence of the mediator; (2) the independent variable must be significantly related to the mediator; and (3) when both the independent variable and mediator are included in a model, the direct relationship should become significantly smaller, indicating partial mediation, or become not significant, indicating full mediation.

As the first two criteria have been satisfied by our preceding analyses (see Table 2 and Table 3), we proceeded to test for the third condition. When the mediator is introduced, the relationship between job satisfaction and unionization reduced to $-0.572(p<0.01)$, indicating a partial mediating effect. Hence, $\mathrm{H} 4$ is supported. 


\section{Discussion}

After the reformation of Chinese economic system, Chinese labor unions are gradually changing their role from a predominantly status-quo maintenance organization to one that fights for labor rights (Zhang, 2009). Although the character of Chinese unions has changed substantially, it is still fundamentally different from their western counterparts. While Chinese unions protect the workforce's labor rights, they also have a duty in helping to maintain social stability of the country. When employees are treated unfairly, Chinese unions negotiate with their company on behalf of employee benefits and act as an arbitrator between the workforce and management. This is one way to ensures that conflicts between the different classes would not escalate to a wider scale and disrupt social order.

While unionization has been extensively studied by Western scholars, similar research is still lacking in East Asia, especially in China (Zhang, 2009). That is perhaps because for a long time, unions in China were mostly organized by officials from the central government, not by the workforce. Unions were not of much help to the employees when they received unfair treatments, and employees did not trust labor unions or felt motivated to join it. In this study, we examined the triadic relationships between job satisfaction, union instrumentality and unionization from a Chinese perspective, and found that career prospect, work environment, compensation and benefit and union instrumentality were predictive of unionization. Moreover, union instrumentality was found to mediate the relationship between job satisfaction and unionization. That is to say, job satisfaction influences individuals' decision on whether to join a union via two mechanisms: through its direct effect on unionization and its indirect effect on unionization via its influence on individuals' perception of union instrumentality.

\section{Contributions and Implications}

The main contribution of this paper is that it adapted and tested a number of western industrial relation theory in a Chinese context. Hitherto, Chinese academics were mainly interested in the topic of whether labor unions could represent employee rights and whether labor unions are independent from the government (Zhang, 2009). The current study contributed to the gap in Chinese-context research by examining the relationships between job satisfaction, unionization and union instrumentality of Chinese employees.

Using Friedman et al. (2006) framework, this paper operationalized job satisfaction into four dimensions - career prospect, working environment, working stress, and compensation and benefits. When Friedman et al. (2006) tested their model on a United States sample, all four dimensions were found to have significant relationships with unionization. However, when Zientara and Kuczyński (2009) applied the model on a Poland sample, they were only able to find a significant relationship between career prospect and unionization. In the current 
research, we found that other than working stress, all the other three components had a significant negative relationship with unionization. This is consistent with the key tenet of culture research: even if something works somewhere, it does not mean that it will work everywhere $(\mathrm{Ng} \& \mathrm{Ng}, 2014)$.

In the Chinese context, career prospect, working environment, and compensation and benefits were found to have significant negative association with unionization. Among them, compensation and benefits had the strongest correlation. To the best of our knowledge, this finding is unique in the sense that it is only found in China. One potential explanation would be the increasingly high living cost of the Chinese society is placing a growing stress on the workforce. The rich-poor gap of China is getting wider, and the social welfare system has much room left for improvements. Hence, economic factor could become a chief motivation for individuals needing a helping hand to unionize. Nevertheless, as mentioned in this paper's introduction part, there were quite a number of labor-management conflicts recently that received public attention ended up with the employees getting more compensations and benefits. The reports of these events might also have primed the respondents to have a greater emphasis on compensations and benefits related issues when they were answering labor union related questions. Yet, if this was the case, we could expect more compensation and benefits related labor movements to occur in the future. This will only provide further support for our findings but not vitiate its validity.

Different from previous researches, working stress was not found to have a significant influence on unionization. We believe the cause of this observation is the cultural values of the Chinese labor force (Wang \& Zhang, 2012). Although some traditional values were weakened as the country got industrialized and westernized, some essential values such as respecting and yielding to the authority remained steadfast in the Chinese's culture (Hofstade, 1998; Wang \& Chu, 2008). It is still a common sight in the workplace for superiors to have supreme authority over their subordinates. When an order is given by the superior, the subordinates tend not to question the order. Hence, we can expect that when heavier work loads are placed on the labor force, they might not even be aware that they are treated unfairly as they might be very well used to such acts. Nevertheless, as we did not examine the effect of cultural values in this research, we invite management scholars to consider this factor in their future studies.

\section{Limitation and Future Direction of Research}

The first limitation of this research was the limitation on the geographic range of our samples. Due to cost reasons and resource constrains, the survey was only conducted in China's Jiangsu Province. This might cause the results of this research to have limited generalizability. However, considering that the data were collected from 30 different companies, we believe the 
results should still be generalizable to other contexts. Future researches should be conducted in other parts of China or even other countries to examine our results' generalizability to other contexts.

Second, this research relied only on subjective data. Although the results of our analyses did not reflect that the data had problems with common method bias, it is always preferable to have the results of findings triangulated by the use of objective data whenever such data are available (Neuman, 2006). Unfortunately, for the current research, we were not able to get such objective data due to administrative and political reasons. Future researchers can test the relationships proposed in this study with objective data such as rate of successful labor movements, number of employees joining unions based on the records of union membership log books, etc.

Third, although we found some evidence that union instrumentality was associated with job satisfaction, we did not know what type of union actions could result in what type of job satisfaction and to what extent. In addition, we did not know how labor movements could unfold to bring such job satisfaction to employees nor how should it unfold. Future researchers can consider carrying out a grounded theory research to explore such processes to fill the current gap in knowledge.

\section{Acknowledgments}

This work was done with help with these foundation items: Project (71573123 and 71473131) supported by the National Natural Science Foundation of China; Qing Lan Project of Jiangsu Province of the Young Academic Leaders; Six talent peaks project in Jiangsu Province

\section{References}

Anwar, S., \& Sun, S. (2015). Unionisation and Firm Performance in China's Manufacturing Industries. Journal of Labor Research, 36(1), 78-102. http://dx.doi.org/10.1007/s12122-014-9197-1

Berkowitz, M. (1954). The Economics of labor union organization and administration. Industrial and Labor Relation Review, 7(4), 575-592. http://dx.doi.org/10.1177/001979395400700405

Blanchflower, D. G. (2006). A cross-country study of union membership. Dartmouth College NBER and IZA Bonn, Discussion Paper n 2016.

Booth, A.L. (1985). The free rider problem and a social custom model of labor union membership. Quarterly Journal of Economics, 100, 253-261. http://dx.doi.org/10.2307/1885744 
Budd, J., Chi, W., Wang, Y., \& Xie, Q. (2014). What Do Unions in China Do? Provincial-Level Evidence on Wages, Employment, Productivity, and Economic Output. Journal of Labor Research, 35(2), 185-204. http://dx.doi.org/10.1007/s12122-014-9178-4

Charlwood, A. (2002). Why do non-union employees want to unionize? Evidence from Britain. British Journal of Industrial Relations, 40, 463-491. http://dx.doi.org/10.1111/1467-8543.00243

DeCotiis, T.A., \& LeLouarn, J.Y. (1981). A predictive study of voting behavior in a representation election using union instrumentality and work perceptions. Organizational Behavior and Human Performance, 27, 103-118. http://dx.doi.org/10.1016/0030-5073(81)90041-6

Deery, S., \& Cieri, H. (1991). Determinants of labor union membership in Australia. British Journal of Industrial Relations, 29, 59-73.

Dhammika, K.A., Fias, F.B., \& Sam, T.L. (2012). Union politicization in Sri Lanka: dimensions and measurements. Wyamba Journal of Management, 1(1), 12-23.

Ding, J., \& Wang, H. (2014). Labor unions have been established in all townships and subdistricts in Zhejiang Province with one million new members. Zhejiang Online News. Available at: http://www.zjol.com.cn

Field, A. (2009). Discovering Statistics Using SPSS ( $3^{\text {rd }}$ ed.). California: Sage Publications.

Fiorito, J., \& Greer, C.R. (1982). Determinants of US unionism: Past research and future needs. Industrial Relations: A Journal of Economy and Society, 21, 1-32. http://dx.doi.org/10.1111/j.1468232X.1982.tb00212.x

Friedman, B.A., Abraham, S.E., \& Thomas, R.K. (2006). Factors related to employees' desire to join and leave unions. Industrial Relations: A Journal of Economy and Society, 45, 102-110. http://dx.doi.org/10.1111/j.1468-232x.2006.00416.x

Friedman, E.D. (2014). Economic Development And Sectoral Unions In China. Industrial \& Labor Relations Review, 67(2), 481-503. http://dx.doi.org/10.1177/001979391406700208

Ge, Y. (2007). What Do Unions Do in China?. SSRN Electronic Journal. http://dx.doi.org/10.2139/ssrn.1031084

Goeddeke, F.X., \& Kammeyer-Mueller, J.D. (2010). Perceived support in a dual organizational environment: Union participation in a university setting. Journal of Organizational Behavior, 31, 65-83. http://dx.doi.org/10.1002/job.629

Guest, D.E., \& Dewe, P. (1988). Why do workers belong to a labor union?: A social psychological study in the UK electronics industry. British Journal of Industrial Relations, 26, 178-194. http://dx.doi.org/10.1111/j.1467-8543.1988.tb00745.x 
Haberfeld, Y. (1995). Why do workers join unions? The case of Israel. Industrial \& Labor Relations Review, 48(4), 656-670. http://dx.doi.org/10.1177/001979399504800404

Heneman III, H.G., \& Sandver, M.H. (1982). Predicting the outcome of union certification elections: A review of the literature. Industrial and Labor Relations Review, 36, 537-559. http://dx.doi.org/10.1177/001979398303600402

Hofstede, G. (1998). Attitudes, values and organisational culture: Disentangling the concepts. Organisation Studies, 19, 477-493. http://dx.doi.org/10.1177/017084069801900305

Hu, E. (2012). Study on the industrial relationship and dual commitment in Chinese context. Economic Management Journal, 34, 66-75.

Iverson, R.D., \& Kuruvilla, S. (2007). Antecedents of union loyalty: The influence of individual dispositions and organizational context. Journal of Organizational Behavior, 16: 557-582. http://dx.doi.org/10.1002/job.4030160605

James, L.R., \& Brett, J.M. (1984). Mediators, moderators, and tests for mediation. Journal of Applied Psychology, 69(2), 307. http://dx.doi.org/10.1037/0021-9010.69.2.307

Khaleque, A. (1993). Labor unionism, job attitudes, and satisfaction of workers in Bangladesh. Journal of Applied Psychology, 42, 277-284. http://dx.doi.org/10.1111/j.1464-0597.1993.tb00743.x

Klandermans, B. (1986). Psychology and labor union participation: Joining, acting, quitting. Journal of Occupational Psychology, 59, 189-204. http://dx.doi.org/10.1111/j.20448325.1986.tb00224.x

Klingner, D.E., Nalbandian, J., \& Llorens, J. (2010). Public Personnel Management: Contexts and Strategies. 6th ed. New York: Longman.

Kochan, T.A. (1979). How American workers view labor unions. Monthly Labor Review, 102, 23-31.

Li, G. (2013a). Strike continues in Cooper Chengshan and the merger comes to deadlock. China Business News, A5.

Li, L. (2013b). Pudong Jinqiao labor union resolves labor conflicts through assisting companies, securing positions, and promoting stability. Jiefang Daily. Available at: http://www.jfdaily.com

Lu, Y., Tao, Z.; \& Wang, Y. (2009). Union effects on performance and employment relations: Evidence from China. SSRN Electronic Journal, 21(1), 202-210. 
Masterson, S.S., Lewis, K., Goldman, B.M., \& Taylor, M.S. (2000). Integrating justice and social exchange: The differing effects of fair procedures and treatment on work relationships. Academy of Management Journal, 43(4), 738-748. http://dx.doi.org/10.2307/1556364

Neuman, W. (2006). Social research methods: qualitative and quantitative approaches $\left(6^{\text {th }}\right.$ ed. $)$. USA: Pearson Education.

Ng, J.C.Y., \& Ng, K.Y.N. (2014). Culture, organisational culture and organisation climate: An integrative approach. Indian Journal of Commerce \& Management Studies, 5(2), 18-26.

Parkes, K.R., \& Razavi, T.D.B. (2004. Personality and attitudinal variables as predictors of voluntary union membership. Personality and Individual Differences, 37, 333-347. http://dx.doi.org/10.1016/j.paid.2003.09.007

Premack, S.L., \& Hunter, J.E. (1988). Individual unionization decisions. Psychological Bulletin, 103(2), 223-234. http://dx.doi.org/10.1037/0033-2909.103.2.223

Schnabel, C., \& Wagner, J. (2007). Union density and determinants of union membership in 18 EU countries: evidence from micro data, 2002/03. Industrial Relations Journal, 38, 5-32. http://dx.doi.org/10.1111/j.1468-2338.2007.00433.x

Schriesheim, C.A. (1978). Job satisfaction, attitudes toward unions, and voting in a union representation election. Journal of Applied Psychology, 63(5), 548-552. http://dx.doi.org/10.1037/0021-9010.63.5.548

Smith, P.C., Hulin, C.L., \& Kendall, L.M. (1969). The measurement of satisfaction in work and retirement: A strategy for the study of attitudes. Chicago: Rand McNally \& Company.

Visser, J. (2002). Why fewer workers join unions in Europe: A social custom explanation of membership trends. British Journal of Industrial Relations, 40, 403-430. http://dx.doi.org/10.1111/1467-8543.00241

Voos, P.B. (1983). Union organizing: Costs and benefits. Industrial \& Labor Relations Review, 36(4), 576-591. http://dx.doi.org/10.1177/001979398303600404

Waddington, J., \& Whitston, C. (1997). Why do people join unions in a period of membership decline? British Journal of Industrial Relations, 35, 515-546. http://dx.doi.org/10.1111/14678543.00067

Wang, L., \& Chu, X. (2008). Psychological contract violation and employees work outcomes: The moderating role of Chinese traditionality. Soft Science, 22, 137-140.

Wang, Q., \& Zhang, J. (2012). Confucian traditional values at workplace: Theory, measurement and validation. Nankai Business Review, 15, 66-79. 
Wheeler, H.N., \& McClendon, J.A. (1991). The Individual Decision to Unionize. The state of the unions, 47.

White, G. (1996). Chinese labor unions in the transition from Socialism: Towards corporatism or civil society? British Journal of Industrial Relations, 34, 433-457. http://dx.doi.org/10.1111/j.1467-8543.1996.tb00483.x

Xu, X. (2010). Dual roles of Chinese unions. Journal of Humanities, 6, 151-160.

Yao, C. (2013), October 10. Benefits of setting up labor unions in foreign-funded enterprises. Jiangsu Worker News, 2.

Yao, X., Li, M., \& Han, J. (2009). Labor union's role in labor relations: An empirical analysis of Zhejiang Province. Journal of China Institute of Industrial Relations, 2, 25-30.

You, Z. (2012). How to understand the function of labor rights protection in Chinese unions. Jiangsu Social Science, 6, 6-9.

Youngblood, S.A., Denisi, A.S., Molleston, J.L., \& Mobley, W.H. (1984). The impact of work environment, instrumentality beliefs, perceived labor union image, and subjective norms on union voting intentions. Academy of Management Journal, 27(3), 576-590. http://dx.doi.org/10.2307/256046

Zhang, X. (2009). Labor unions Under the Modernization of Paternalist Rule in China. WorkingUSA, 12, 193-218. http://dx.doi.org/10.1111/j.1743-4580.2009.00229.x

Zhao, J. (2008). Labor rights protection provided by unions: study on the internal structure and the dialectical relationship. Journal of China Institute of Industrial Relations, 22, 14-23.

Zientara, P., \& Kuczyński, G. (2009). Employees' Desire to Join or Leave a Union: Evidence from Poland. Industrial Relations: A Journal of Economy and Society, 48, 185-192. http://dx.doi.org/10.1111/j.1468-232x.2008.00550.x

Journal of Industrial Engineering and Management, 2016 (www.jiem.org)

Article's contents are provided on an Attribution-Non Commercial 3.0 Creative commons license. Readers are allowed to copy, distribute and communicate article's contents, provided the author's and Journal of Industrial Engineering and Management's names are included. It must not be used for commercial purposes. To see the complete license contents, please visit http://creativecommons.org/licenses/by-nc/3.0/. 